УДК 81’42:329.11/.12(410+94)

DOI: $10.18523 /$ lcmp2522-9281.2021.7.35-49

Pavlo Zernetsky

https://orcid.org/0000-0003-4952-0747

Olena Kucherova

https://orcid.org/0000-0003-2350-2399

\title{
COGNITIVE MAPS OF DISCOURSES OF BRITISH CONSERVATIVE AND AUSTRALIAN LIBERAL POLITICAL MANIFESTOS
}

The research endeavors to study and determine the influence of cognitive maps on production of political manifestos discourse. The research has been conducted in the framework of Sociocognitive Discourse Studies. The results show that discourse cognitive structure of British Conservative Party and Australian Liberal Party manifestos is characterized by different sets of cognitive maps on the level of communicative strategies and somewhat similar sets of cognitive schemas on the level of communicative tactics. Applying the method of interpropositional semantic analysis, the communicative strategy and communicative tactic of comparison was identified in Australian Liberal Party manifesto. Despite the close affinity between political discourses of the UK and Australia, there are significant differences in patterns of information organization in online manifestos of the ruling parties to engage the community and enhance persuasion.

Keywords: cognitive maps, discourse analysis, information processing, political communication, strategies of discourse production, tactics of discourse production.

\section{Introduction}

In our digital age political communication is becoming more user-friendly. Due to the Internet, citizens can access the information easily to make wise choices. The media affect citizens' levels of political knowledge and opinion formation. The last 20 years have seen the intensification of the use of digital communications technologies, with considerable implications for political (C) Pavlo Zernetsky, Olena Kucherova, 2021 
participation. Considerable interest has been focused on new internet-based technologies and their potential to stimulate democratic improvements around the world (Zernetska, 2017). There has been much research on the interplay between media and democracy (Chen et al., 2006; Graber, 2004) although comparative studies are scarce.

With common historical and political traditions, both the UK and Australia are proud of being the genuine liberal democracies in the modern world. The Parliaments of both countries make decisions that impact all people and the way they live. Parliamentarians have immense power to make laws which reflect the needs and desires of the community. It is important to remember that in any democratic system the role of politicians is to represent the citizens. Politicians form outlook schemas or thinking categories of their electorate. They write their policy promises in manifestos. Thus, the parties' performance during the general election depends much on their manifestos. They can energize the citizens and, in this way, influence the party's representation in the parliament and the Government formation.

In a modern democracy with an educated electorate political parties publish their major policies and promises online, where they are available for voters for 'considered assessment' before elections. As a result, political manifestos have migrated to the internet. A manifesto is a publication issued by a political party before a General Election. It contains the set of policies that the party stands for and would wish to implement if elected to govern. We attempt to analyze and compare the manifestos of the ruling parties of the UK (the Conservative party) and Australia (the Liberal party), which are both center-right and conservative in their ideology.

\section{Theoretical background}

The concept of cognitive context has been incorporated as fundamental in the study of language and discourse. Discourse production itself is understood as a complex cognitive process, which can be described and explained (Zernetskyi, 1992; Zernetsky, \& Kucherova, 2020). A variety of cognitive studies have been conducted to investigate discourse (van Dijk, 2016; Kuranova, 2018; Riabokon, 2016; Shevchenko, 2015; Tenbrink, 2020).

Global and local discourse ordering, the functional relations between propositions or sentences, as well as the schematic categories of text genres, reflect the underlying cognitive strategies applied in mapping information 
(van Dijk, 2011a). Local and global meaning of discourse in terms of propositions and overall patterns of text (superstructure) are based on underlying mental models, which subjectively represent a situation or an event and opinions about this situation. Mental model is a representation of events and situations in 'episodic memory' (the record of all our personal experiences) - as the basis of all discourse production and understanding (Johnson-Laird, 1989; van Dijk, \& Kintsch, 1983). Mental models have a standard schematic structure of a limited number of categories that allow very fast processing.

Originating from the psychological research on spatial cognition, cognitive map is a metaphor for people's mental representations of environmental information. People have definite configurations of concepts about the world which provide guidance for thinking. This configuration of concepts can be visualized as a cognitive map (CM) (Graber, 1984, p. 178). They are hierarchically organized sets of propositions. Applying the model of schema paradigm to political data, D. Graber discusses schemas as thinking categories, which means that schemas have not only comprehension dimensions, but also production dimensions. Within such social psychological analysis, CM relates to mental models that are fixed in the consciousness of the reader when understanding the discourse.

Cognitive mapping is a powerful visual-mapping strategy for organizing and communicating information. Introduced by the psychologist E. Tolman, $\mathrm{CM}$ has a strong spatial connotation - CMs usually refer to the representation of space in the brain (Tolman, 1948). A CM is also defined as "any visual representation of a person's (or a group's) mental model for a given process or concept" (Gibbons, 2019). CMs have no visual rules that they need to obey, there is no restriction on how the concepts and the relationships between them are visually represented. As CMs are socially shared, that is used by social groups, they help us understand how language users tend to conceptualize certain phenomena.

In this article, $\mathrm{CM}$ is understood as the umbrella term for visual representations of mental models. Thus, within a sociocognitive approach a $\mathbf{C M}$ can be defined as a discourse cognitive-oriented form of realization of dominating and repeated communicative strategies for this or that genre of discourse. A Cognitive schema (CS) is a discourse cognitive-oriented form of realization of dominating and repeated communicative tactics.

The intention of the paper is to analyze and compare the CMs and CSs used in online manifestos of British Conservative and Australian Liberal 
political parties as for September 2021. By studying the cognitive aspects of political communication, we deal with the mental representations of language users with the purpose to provide better understanding of discourse production. By decoding and describing such thinking categories projecting an Ideal Reader (Eco, 1979), we aim to describe the process of discourse production as a complex cognitive phenomenon.

We provide information about processing communicative strategies and tactics in a particular area of knowledge. The functionality of discourse and its elements at various levels of description derives from the communicative strategies. Politicians have mental frameworks about story scenarios and are fitting facts into these frameworks to make them meaningful.

\section{Methodology and Methods}

Aiming to describe structures of discourse in terms of various cognitive processes that control language use and discourse, the research has been conducted in the framework of Sociocognitive Discourse Studies that in van Dijk's words "relates discourse structures to social structures via a complex sociocognitive interface" (van Dijk, 2016, p. 28). This method was applied to "reveal how speakers' thoughts and concepts are reflected in language, both explicitly and implicitly" (Tenbrink, 2020, p. 2). The method of interpropositional semantic analysis was applied to describe the communicative strategy and communicative tactic of comparison. Linguistic choices reflect the communicative strategies of language users. For this purpose, the texts of manifestos of British Conservative Party and Australian Liberal Party were analyzed and compared. The texts of these manifestos are presented online on the following sites: www.conservatives.com/our-plan and www.liberal.org.ua/ourplan respectively.

\section{The influence of cognitive maps on production of political manifestos discourse}

On their websites, both British Conservative party and Australian Liberal party use the heading 'Our Plan' for what can be called manifesto. Such explicit use of online systems helps engage the community in new ways and foster grassroots participation and access to policy processes.

Manifestos are important in any election, but especially so in the UK. Mention should be made of Salisbury Convention, which is a kind of unwritten rule 
that makes the House of Commons the dominant chamber. Under this convention, the House of Lords will not block legislation on condition that the item was promised in the governing party's manifesto. This explains why British and Australian online manifestos, which are both called 'Our Plan', are so different.

Australia is trying to follow in UK's footsteps. The Australian Parliament also called the federal Parliament, or the Commonwealth Parliament descends from the Westminster tradition because of colonial period (17881901). And its structure resembles the Government of the United Kingdom, domestically referred to as Her Majesty's Government, albeit with one striking difference. There is nothing like Salisbury Convention, which guarantee that the Lords vote down a Government Bill mentioned in an election manifesto. As a result, while British Conservative party manifesto does not undergo any changes, Australian Liberal party manifesto is being constantly altered and adapted.

Manifestos are leader centered. Success depends much on personal popularity of the leader. UK Conservative manifesto begins with 'Boris Johnson's Guarantee', where the leader of the party pledges certain important developments for the country, and the leader's foreword, which is expressive and compelling, and full of metaphors, for example: this country has felt trapped, like a lion in a cage; like some super-green supercar blocked in the traffic. In addition, the manifesto frequently mentions the party: with the Conservatives.

Similarly, we can observe Scott Morrison's quotation on Australian Liberal party site, where he states how proud he is of his nation. The manifesto often mentions the party, calling it by the leader's name: The Morrison Government and even includes direct quotations, such as: In the words of the Prime Minister: "It's our waste, it's our responsibility".

Manifestos are composed of global topics or themes (or frames) (Dijk, 2016, p. 36) as semantic macrostructures that model how they are understood. These macrostructures, which are interpreted as the underlying mental models, cover the main issues that concern the society and are organized in sections. Presenting their policies, the political parties use the rhetorical method of information organization that is called 'order-of importance', decreasing strategy. This means that each party begins with the most important issue. 
British Conservative Party have four very broad sections, such as 'Strengthening our NHS', 'Investing in schools', 'A strong economy', and 'Safer streets'. Their main message is to "get Brexit done," and the UK's withdrawal from the EU dominates their manifesto. Other key policies in their manifesto include ruling out increases in income tax, VAT (value added tax), and National Insurance rates; introducing an Australian-style points-based immigration system; and increased police, education, and health spending. Within these sections we have singled out such global topics as Brexit, Health, Education, Economy, Law and Order.

Australian Liberal Party have eighteen sections, such as 'Rebuilding our Economy', 'Supporting Small Business', 'Lower Taxes', 'Helping with the Cost of Living', 'Building Infrastructure', 'Support For Families', 'Better Health Care', 'Opportunities for Young Australians', 'Supporting Older Australians', 'Supporting Australian Women', 'Protecting Our Environment', 'Lower Power Prices', 'Keeping Australians Safe', 'A Stronger Defence Force', 'Strong Border Protection', 'Backing Regional Australia', 'Tackling Union Lawlessness', and 'Fast And Efficient Broadband'. The Liberal Party begins with the 'economic recovery plan', calling the Australia's economy as 'resilient'. Almost every section begins with the assertion that they 'have an economic plan for Australia', which should result in 'building a stronger $21^{\text {st }}$ Century Australia.' The manifesto finishes with the quotation "Our Plan will deliver a strong, prosperous economy and a safe, secure Australia", which becomes a recurring theme in the manifesto and a slogan. Within these sections we have singled out such global topics as Economy, Supporting small business, Tax, Health, Education, and Climate change.

The schematic superstructures help organize the overall meaning or macrostructure of the text of the manifesto. In van Dijk's words, such a schema is a set of specific categories that are organized according to some flexible and context dependent rules or strategies (van Dijk, 2011). "Schemas represent social learning. Like other forms of learning, schemas are acquired from early childhood onward through overt teaching or operate conditioning and through imitating behaviour observed in others. They may also result from independent discovery through actual personal experiences or through abstract reasoning processes." (Graber, 1984, p. 147) From neo-rhetorical perspective such 
schemas are projected by the author while discourse production. These schemas are regarded as the author's thinking categories that are projected on discourse processing (perception).

D. Graber mentions five dimensions characteristic for processing news discourse, around which schemas about various public policies generally revolve (Graber, 1984, p. 150). These dimensions are (1) statements about who or what caused problems; (2) statements about the nature of institutions involved in the policy; (3) statements concerning the role played by human actors; (4) statements about the policy in terms of cultural values; and (5) statements about the policy's relation to humanistic concerns. She goes on to outline specific types of dimensions in processing schemas, such as simple situation sequences, cause-and-effect sequences including the subtypes 1) simple causal linkages, 2) projections to the future, 3) complex causal linkages; person judgements 1) general human behaviour schemas, 2) politicians; institution judgements including 1) institutional activities, 2) behavioral norms; cultural norms; human interest and empathy (Graber, 1984, pp. 154173). We have applied these dimensions for the analysis of the global topics in British Conservative Party and Australian Liberal Party manifestos because they are characteristic for political discourse. We have also added comparison schema dimensions which is based on semantic interpropositional relations of comparison (Zernetskyi, 1992, pp. 59-97) and realizes speech intention of the author to establish resemblance or difference between the objects of description.

In terms of discourse organization, the text of manifestos is understood as a Speech Event that consists of Speech Transactions, which are referred to as global topics of manifestos. Speech Moves make its micro-topics and correspond to a paragraph of manifestos. The smallest unit in our analysis is Speech Act that corresponds to a predicative unit which consists of proposition and communicative-pragmatic component. Communicative tactics connect Speech Acts of the discourse, which are presented by sentences. Communicative strategies connect Speech Transactions, which are presented by several sentences and/or are repeated in manifestos.

Dominating and repeated communicative strategies for processing political information that constitute $\mathrm{CMs}$ and dominating and repeated communicative tactics that constitute CSs are represented in Table 1 and Table 2 below. 
CMs and CSs of British Conservative Party manifesto

\begin{tabular}{|c|c|c|}
\hline $\mathrm{CM}$ & $\mathrm{CS}$ & Example \\
\hline \multicolumn{3}{|r|}{ Brexit } \\
\hline $\begin{array}{l}\text { Cause-and- } \\
\text { effect }\end{array}$ & & $\begin{array}{l}\text { By keeping our economy strong, we've been able to } \\
\text { support our NHS since } 2010 \text {. But because of the Brexit } \\
\text { deadlock it recently hasn't had the attention it deserves. } \\
\text { That's why we need to get Brexit done and get on with } \\
\text { bringing the change people voted for }\end{array}$ \\
\hline \multicolumn{3}{|r|}{ Health } \\
\hline \multirow{4}{*}{$\begin{array}{l}\text { Projections } \\
\text { to the } \\
\text { future }\end{array}$} & & The NHS budget will go up by £33.9 billion by 2023-24. \\
\hline & Person & $\begin{array}{l}\text { We're making sure the NHS has the resources it needs so } \\
\text { that it can provide everyone with the best possible care. } \\
\text { Over } 1 \text { million NHS staff - nurses, midwives and } \\
\text { cleaners - are getting a well-deserved pay rise of at least } \\
6.5 \% \text { per cent and doctors will also see their pay } \\
\text { increase. }\end{array}$ \\
\hline & Institution & $\begin{array}{l}\text { Giving the NHS its biggest cash boost in history, and } \\
\text { making sure this funding gets to your local hospital and } \\
\text { GPs. } \\
78 \text { hospital trusts will receive state-of-the-art MRI, CT } \\
\text { and mammography screening machines. }\end{array}$ \\
\hline & $\begin{array}{l}\text { Human } \\
\text { interest and } \\
\text { empathy }\end{array}$ & $\begin{array}{l}\text { We will improve staff morale with more funding for } \\
\text { professional training and more supportive hospital } \\
\text { management. }\end{array}$ \\
\hline \multicolumn{3}{|r|}{ Education } \\
\hline \multirow[t]{3}{*}{ Person } & & $\begin{array}{l}\text { We want every parent to be confident that their children } \\
\text { are getting the best start in life, one that will allow them } \\
\text { to fulfil their potential and put them on a path to a } \\
\text { brighter future. }\end{array}$ \\
\hline & $\begin{array}{l}\text { Projections } \\
\text { to the } \\
\text { future }\end{array}$ & $\begin{array}{l}\text { In the biggest reform to teacher pay in a generation, } \\
\text { salaries for new teachers will be increased to £30,000 by } \\
2022-23 \text { and we're funding increased contributions into } \\
\text { the Teachers' Pension Scheme so that school leaders can } \\
\text { focus as much of their resources as possible on the front } \\
\text { line. }\end{array}$ \\
\hline & $\begin{array}{l}\text { Behavioral } \\
\text { norms }\end{array}$ & $\begin{array}{l}\text { We will continue to help teachers tackle bullying, } \\
\text { including homophobic bullying. No child should be } \\
\text { bullied on account of who their parents are or where } \\
\text { they come from. }\end{array}$ \\
\hline
\end{tabular}




\begin{tabular}{|c|c|c|}
\hline $\mathrm{CM}$ & $\mathrm{CS}$ & Example \\
\hline \multicolumn{3}{|r|}{ Economy } \\
\hline \multirow[t]{5}{*}{$\begin{array}{l}\text { Human } \\
\text { interest and } \\
\text { empathy }\end{array}$} & & $\begin{array}{l}\text { The 'triple lock'we introduced has meant that those who } \\
\text { have worked hard and put in for decades can be } \\
\text { confident that the state will be there to support them } \\
\text { when they need it. We will keep the triple lock, the winter } \\
\text { fuel payment, the older person's bus pass and other } \\
\text { pensioner benefits, ensuring that older people have the } \\
\text { security and dignity they deserve. }\end{array}$ \\
\hline & $\begin{array}{l}\text { Cause-and- } \\
\text { effect }\end{array}$ & $\begin{array}{l}\text { We know businesses are at the heart of a successful } \\
\text { economy. That's why we will continue to back businesses } \\
\text { with lower taxes, better infrastructure and strike new } \\
\text { post-Brexit free trade deals around the world to make } \\
\text { people better off here at home. }\end{array}$ \\
\hline & Person & $\begin{array}{l}\text { And we'll help people with the cost of living by making } \\
\text { sure people keep more of the money they earn through } \\
\text { keeping their taxes low. }\end{array}$ \\
\hline & $\begin{array}{l}\text { Projections } \\
\text { to the } \\
\text { future }\end{array}$ & $\begin{array}{l}\text { We will raise the National Insurance threshold to } £ 9,500 \\
\text { next year-representing a tax cut for } 31 \text { million workers. } \\
\text { Our ultimate ambition is to ensure that the first £12,500 } \\
\text { you earn is completely free of tax - which would put } \\
\text { almost } 5500 \text { per year in people’s pockets. }\end{array}$ \\
\hline & Institution & $\begin{array}{l}\text { Our plan to upgrade infrastructure will make it easier for } \\
\text { businesses to operate - to move goods about the country } \\
\text { and to connect to customers around the world via gigabit } \\
\text { broadband. }\end{array}$ \\
\hline \multicolumn{3}{|r|}{ Law and Order } \\
\hline \multirow[t]{4}{*}{$\begin{array}{l}\text { Behavioral } \\
\text { norms }\end{array}$} & & $\begin{array}{l}\text { The increase in serious violence is deeply worrying and } \\
\text { sadly some people no longer feel as safe as they should. }\end{array}$ \\
\hline & Institution & $\begin{array}{l}\text { Things like extending stop and search-where we've } \\
\text { empowered more than } 8,000 \text { police officers with } \\
\text { enhanced powers as part of our efforts to crack down on } \\
\text { violent crime. }\end{array}$ \\
\hline & $\begin{array}{l}\text { Cause-and- } \\
\text { effect }\end{array}$ & $\begin{array}{l}\text { A national recruitment campaign has already begun, } \\
\text { overseen by a new National Policing Board and backed } \\
\text { by } £ 750 \text { million next year. This means that we can start } \\
\text { making people feel safer straight away. }\end{array}$ \\
\hline & $\begin{array}{l}\text { Projections } \\
\text { to the } \\
\text { future }\end{array}$ & $\begin{array}{l}£ 2.75 \text { billion will be spent on creating modern, efficient } \\
\text { prisons to better reform criminals and keep the public } \\
\text { safe, whilst an extra } £ 100 \text { million will aid the crackdown } \\
\text { on crime within prisons. }\end{array}$ \\
\hline
\end{tabular}


CMs and CSs of Australian Liberal Party manifesto

\begin{tabular}{|c|c|c|}
\hline $\mathrm{CM}$ & $\mathrm{CS}$ & Example \\
\hline \multicolumn{3}{|r|}{ Economy } \\
\hline \multirow[t]{3}{*}{ Comparison } & & $\begin{array}{l}\text { In the June } 2020 \text { quarter, Australia's economy con- } \\
\text { tracted by } 7 \% \text {. This compares to around } 11 \% \text { falls in } \\
\text { New Zealand, } 14 \% \text { in France and } 20 \% \text { in the UK. } \\
\text { Without JobKeeper and other measures to support our } \\
\text { economy, Treasury estimates the unemployment rate } \\
\text { would have been } 5 \text { percentage points higher. }\end{array}$ \\
\hline & Person & $\begin{array}{l}\text { A } 50 \% \text { wage subsidy, supporting } 180,000 \text { existing } \\
\text { apprentices and trainees and 100,000 new apprentice- } \\
\text { ships and traineeships. }\end{array}$ \\
\hline & $\begin{array}{l}\text { Projections } \\
\text { to the } \\
\text { future }\end{array}$ & $\begin{array}{l}\text { The Morrison Government will continue to deliver on } \\
\text { our economic recovery plan. } \\
\text { The JobMaker Hiring Credit will support nearly half a } \\
\text { million young Australians in work. }\end{array}$ \\
\hline \multicolumn{3}{|r|}{ Supporting small business } \\
\hline \multirow[t]{3}{*}{ Institution } & & $\begin{array}{l}\text { Over } 1 \text { million businesses and over } 3.8 \text { million workers } \\
\text { were supported by the first phase of JobKeeper - the } \\
\text { largest economic support program in Australia's history. }\end{array}$ \\
\hline & $\begin{array}{l}\text { Simple } \\
\text { situation }\end{array}$ & $\begin{array}{l}\text { Small businesses are the backbone of our economy. } \\
\text { The Morrison Government is supporting them through } \\
\text { the COVID recession, so they can rebuild and create } \\
\text { jobs during the recovery. }\end{array}$ \\
\hline & Person & $\begin{array}{l}\text { A new JobMaker Hiring Credit will encourage busi- } \\
\text { nesses to hire younger Australians. }\end{array}$ \\
\hline \multicolumn{3}{|r|}{ Tax } \\
\hline \multirow[t]{3}{*}{ Person } & & $\begin{array}{l}\text { In } 2019 \text {, the Morrison Government legislated tax relief } \\
\text { so people could keep more of what they earn. }\end{array}$ \\
\hline & $\begin{array}{l}\text { Cause-and- } \\
\text { effect }\end{array}$ & $\begin{array}{l}\text { Now the Government has brought forward Stage Two of } \\
\text { our legislated tax cuts by two years. } \\
\text { This means more than } 11 \text { million taxpayers are getting a } \\
\text { tax cut backdated to } 1 \text { July } 2020 \text {. }\end{array}$ \\
\hline & $\begin{array}{l}\text { Projections } \\
\text { to the } \\
\text { future }\end{array}$ & $\begin{array}{l}\text { This tax relief is part of a major reform to our tax system } \\
\text { that will see around } 95 \% \text { of taxpayers face a marginal } \\
\text { rate of no more than } 30 \text { cents in the dollar in 2024-25. }\end{array}$ \\
\hline \multicolumn{3}{|r|}{ Health } \\
\hline $\begin{array}{l}\text { Simple } \\
\text { situation }\end{array}$ & & $\begin{array}{l}\text { Over } 550 \text { COVID-19 clinics have opened, including up } \\
\text { to } 150 \text { GP-led respiratory clinics. } \\
\text { Over } 15 \text { million COVID- } 19 \text { tests have been conducted. }\end{array}$ \\
\hline
\end{tabular}




\begin{tabular}{|c|c|c|}
\hline \multirow[t]{3}{*}{$\mathrm{CM}$} & $\mathrm{CS}$ & Example \\
\hline & $\begin{array}{l}\text { Compari- } \\
\text { son }\end{array}$ & $\begin{array}{l}\text { Federal funding for public hospitals will more than } \\
\text { double compared to Labor }-\$ 13.3 \text { billion in } 2012-13 \\
\text { to } \$ 29.9 \text { billion in } 2024-25 \text {. }\end{array}$ \\
\hline & Person & $\begin{array}{l}\text { More Australians are now seeing their doctor without } \\
\text { having to pay. Nearly } 9 \text { out of } 10 \text { visits are now free. }\end{array}$ \\
\hline \multicolumn{3}{|r|}{ Education } \\
\hline \multirow[t]{4}{*}{ Institution } & & $\begin{array}{l}\text { Our guaranteed funding commitment invests } \$ 315 \\
\text { billion in schools over the next decade (from } 2018 \text { to } \\
\text { 2029). }\end{array}$ \\
\hline & Person & $\begin{array}{l}\text { We are improving teacher quality by testing trainee } \\
\text { teachers to ensure they are in the top } 30 \% \text { for literacy } \\
\text { and numeracy before they can teach. }\end{array}$ \\
\hline & $\begin{array}{l}\text { Behavioral } \\
\text { norms }\end{array}$ & $\begin{array}{l}\text { We have committed to the National Schools Chaplaincy } \\
\text { program on a permanent basis, with a new anti-bullying } \\
\text { focus. }\end{array}$ \\
\hline & $\begin{array}{l}\text { Projections } \\
\text { to the } \\
\text { future }\end{array}$ & $\begin{array}{l}\text { Under the Job-ready Graduates Package of reforms to } \\
\text { higher education, government university funding of } \$ 18 \\
\text { billion in } 2020 \text { will grow to } \$ 20 \text { billion by } 2024 \text {. }\end{array}$ \\
\hline \multicolumn{3}{|r|}{ Climate change } \\
\hline \multirow[t]{4}{*}{$\begin{array}{l}\text { Simple } \\
\text { situation }\end{array}$} & & $\begin{array}{l}\text { Australia accounts for } 1.3 \% \text { of global emissions. We } \\
\text { have made significant commitments to reduce our } \\
\text { emissions. } \\
\text { Australia beat its } 2020 \text { Kyoto targets by } 459 \text { million } \\
\text { tonnes. }\end{array}$ \\
\hline & $\begin{array}{l}\text { Projections } \\
\text { to the } \\
\text { future }\end{array}$ & $\begin{array}{l}\text { We are on track to beat our Paris commitment to reduce } \\
\text { emissions by } 26 \text { to } 28 \text { per cent below } 2005 \text { levels by } \\
2030 \text {. }\end{array}$ \\
\hline & $\begin{array}{l}\text { Compari- } \\
\text { son }\end{array}$ & $\begin{array}{l}\text { On a per-person basis, this is a greater reduction than } \\
\text { the commitments of the EU, Germany, Canada, New } \\
\text { Zealand or Japan. }\end{array}$ \\
\hline & Institution & $\begin{array}{l}\text { Each federal electorate will receive up to } \$ 150,000 \text { this } \\
\text { year for projects. }\end{array}$ \\
\hline
\end{tabular}

As it can be seen from Table 1 and Table 2, different types of communicative strategies and communicative tactics are prominent in the manifestos that are compared. Thus, CMs of British Conservative Party manifesto are discourse cognitive-oriented form of realization of communicative strategies of Cause-and-effect, Projections to the future, Person, Human interest and empathy, and Behavioral norms, while CMs of Australian Liberal Party manifesto 
are discourse cognitive-oriented form of realization of Comparison, Institution, Person, and Simple situations. It is obvious that the only communicative strategy that is common for both manifestos is Person. Furthermore, the data show that communicative strategy and communicative tactic of Comparison are frequently used in CMs and CSs of Australian Liberal Party manifesto but is absent in British Conservative Party manifesto.

British Conservative Party manifesto and Australian Liberal Party manifesto have some common global topics: Education, Economy and Health. However, CMs are different for these topics:

- (1) Education (CM Person in British Conservative Party manifesto, but CM Institution in Australian Liberal Party manifesto with CS Person. The manifestos have two similar CSs, Behavioral norms and Projections to the future, and CS Person in Australian Liberal Party manifesto.);

- (2) Economy (CM Human interest in British Conservative Party manifesto, whereas CM Comparison in Australian Liberal Party manifesto. CSs are partially similar: Person and Projections to the future are used in both manifestos; however, Cause-and-Effect is used only in British Conservative Party manifesto.);

- (3) Health (CM Projections to the future in British Conservative Party manifesto, while CM Simple situation in Australian Liberal Party manifesto. CSs are quite different: Person, Institution, and Human interest and empathy in British Conservative Party manifesto, when Person and Comparison in Australian Liberal Party manifesto.).

Other global topics are different: Brexit, Health, Law and Order in British Conservative Party manifesto, but Supporting small business, Tax, and Climate change in Australian Liberal Party manifesto.

\section{Conclusions}

Overall, discourse cognitive structure of British Conservative Party and Australian Liberal Party manifestos is characterized by different sets of CMs on the level of communicative strategies and somewhat similar sets of CSs on the level of communicative tactics. CMs of British Conservative Party manifesto are discourse cognitive-oriented form of realization of communicative strategies of Cause-and-effect, Projections to the future, Person, Human interest and empathy, and Behavioral norms. In contrast, CMs of Australian Liberal Party manifesto are discourse cognitive-oriented form of realization of Comparison, Institution, Person, and Simple situations. Moreover, communi- 
cative strategy and communicative tactic of comparison are used in CMs and CSs of Australian Liberal Party manifesto but is absent in CMs and CSs of British Conservative Party manifesto. On the whole, British Conservative Party manifesto and Australian Liberal Party manifesto differ markedly in global topics. They have three common global topics, such as Education, Economy, and Health. Other global topics are different for two manifestos.

It can therefore be concluded that despite the close affinity between political discourses of the UK and Australia, there are significant differences in patterns of information organization in online manifestos of the ruling parties to engage the community and enhance persuasion. As political documents play a significant role nowadays in political communication, which has been intensified using digital communication technologies, we view it crucial to consider political elite's performance in the future analysis of communication.

\section{References}

Chen, P., Gibson, R., \& Geiselhart, K. (2006). Electronic democracy? The impact of new communications technologies on Australian democracy. The Australian National University.

Dijk, van T. A. (2011a). Issues in functional discourse analysis. In H. Pinkster, \& I. Genee (Eds.), Unity in Diversity: Papers Presented to Simon C. Dik on his 50 th Birthday (pp. 27-46). Berlin, Boston: De Gruyter Mouton. https://doi.org/10.1515/9783110847420.27

Dijk, van T. A. (2011b). News analysis: Case studies of international and national news in the press. Routledge.

Dijk, van T. A. (2016). Sociocognitive discourse studies. In J. Richardson, \& J. Flowerdew (Eds.), Handbook of discourse analysis (pp. 26-43). London: Routledge.

Dijk, van T. A., \& Kintsh, W. (1983). Strategies of discourse comprehension. New York: Academic Press.

Eco, U. (1979). The role of the reader: Explorations in the semiotics of texts. Bloomington: Indiana University Press.

Gibbons, S. (2019, July 14). Cognitive maps, mind maps, and concept maps: definitions. Nielsen Norman Group. Retrieved from https://www.nngroup.com/articles/cognitive-mind-concept/.

Graber, D. (2004). Mediated politics and citizenship in the twenty-first century. Annual review of psychology, 55, 545-571. https://doi.org/10.1146/annurev.psych.55.090902.141550

Graber, D. (1984). Processing the news: How people tame the information tide. Longman.

Johnson-Laird, P. N. (1989). Mental Models. In Foundations of Cognitive Science (pp. 469-499). Cambridge (Mass.), London: MIT press.

Kuranova, S. (2018). Stratehiyi, taktyky ta pryyomy movlennyevoyi diyal'nosti yak komponent modelyuvannya dyskurs-portreta movnoyi osobystosti [Strategies, tactics and ways of speech activity as a component of modelling of discourse portrait of language personality]. Mova: klasychnemoderne - postmoderne [Language: classic - modern - postmodern], 4, 33-47 [in Ukrainian]. https://doi.org/10.18523/lcmp2522-92812018156148

Riabokon, H. L. (2016). Teoriya freymiv kriz' pryzmu prahma-semantychnoyi pobudovy dyskursu [Theory of frames through the prism of pragma-semantic structure of discourse]. Naukovi zapysky 
NaUKMA. Filolohichni nauky (Movoznavstvo) [Academic notes of NaUKMA. Philology (Linguistics)], 189, 76-82. Retrieved from http://nbuv.gov.ua/UJRN/NaUKMAfn_2016_189_17 [in Ukrainian].

Shevchenko, I. S. (2015). Diskurs kak kognitivno-kommunicativnyi fenomen: edinicy i kategorii [Discourse as cognitive-communicative phenomenon: units and categories]. Lingvisticheskie issledovanija: sbornik statey EGU, 5, 146-158 [in Russian].

Tenbrink, T. (2020). Cognitive discourse analysis: An introduction. Cambridge: Cambridge University Press. https://doi.org/10.1017/9781108525176

Tolman, E. C. (1948). Cognitive maps in rats and men. The Psychological Review, 55 (4), 182-208.

Zernetska, O. V. (2017). Hlobal'na komunikarsiya: monohrafiya [Global communication: monography]. Kyiv: Naukova dumka [in Ukrainian].

Zernetskyi, P. V. (1992). Riechievoie obshchieniye na anhliyskom iazykie (Kommunikativno-funktsionalnyi analiz diskursa) [Speech communication in English (Communicative-functional discourse analysis)]. Kiev: Lybid [in Russian].

Zernetsky, P., \& Kucherova, O. (2020). Semantic structures of the American blog discourse. Mova: klasychne-moderne-postmoderne [Language: classic-modern-postmodern], 6, 5-16. https:// doi.org/10.18523/lcmp2522-9281.2020.6.5-16

Павло Зернецьький, Олена Кучерова

\section{КОГНІТИВНІ МАПИ ДИСКУРСІВ ПОЛІТИЧНИХ МАНІФЕСТІВ БРИТАНСЬКОЇ КОНСЕРВАТИВНОЇ І АВСТРАЛІЙСЬКОЇ ЛІБЕРАЛЬНОЇ ПАРТІЙ}

Постановка проблеми. Когнітивні мапи (КМ) - це дискурсивна когнітивно-орієнтована форма реалізації панівних і повторюваних комунікативних стратегій у дискурсі. Когнітивна схема (КС) - це дискурсивна когнітивно-орієнтована форма реалізації панівних і повторюваних тактик у дискурсі.

Мета статті. Метою дослідження $є$ аналіз та порівняння використання КМ і КС в онлайн-маніфестах британської консервативної та австралійської ліберальної політичних партій станом на вересень 2021 р.

Методи дослідження. Дослідження було проведено в рамках соціокогнітивного дискурс-аналізу. Для опису комунікативної стратегії і комунікативної тактики порівняння було застосовано метод міжпропозиційних семантичних відношень.

Основні результати дослідження. Дискурсивна когнітивна структура досліджуваних маніфестів характеризується різним набором КМ на рівні комунікативних стратегій і дещо схожим набором КС на рівні комунікативних тактик. У маніфесті британської консервативної партії використано такі КМ, як причина-наслідок, прогнози на майбутнє, особистість, 
людський інтерес та емпатія, норми поведінки. Натомість у маніфесті австралійської ліберальної партії використано такі КМ, як порівняння, організація, особистість і прості судження. Зазначимо, що комунікативну стратегію і комунікативну тактику порівняння використано в КМ і КС відповідно в маніфесті австралійської ліберальної партії. Визначено, що досліджувані маніфести відрізняються глобальними темами, серед яких лише три є однакові, а саме: освіта, економіка і здоров'я.

Висновки і перспективи. Результати дослідження свідчать, що незважаючи на спорідненість між політичними дискурсами Великої Британії та Австралії існують істотні відмінності в організації інформації в онлайнманіфестах досліджуваних партій для відповідного впливу на електорат.

Ключові слова: когнітивні мапи, дискурс-аналіз, оброблення інформації, політична комунікація, стратегії побудови дискурсу, тактики побудови дискурсу.

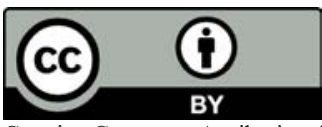

Матеріал надійшов 29.07.2021

Creative Commons Attribution 4.0 International License (CC BY 4.0) 